\title{
PENGARUH STRUKTUR MODAL DAN NPL PADA PERTUMBUHAN ASET SERTA IMPLIKASINYA TERHADAP ROA PADA LPD KABUPATEN TABANAN
}

\author{
Gd Agus Yudha Prasetya $P^{1}$ \\ ${ }^{1}$ Fakultas Ekonomi dan Bisnis Universitas Udayana (Unud), Bali, Indonesia \\ e-mail: gusyudhaprasetya@gmail.com / telp: +6281916480816
}

\begin{abstract}
Return On Assets (ROA) is an important ratio that can be used to measure the ability of a company with investments that have been invested (assets it has) to make a profit. This study aims to determine the effect of capital structure and Non-Performing Loans on Return On Assets (ROA) of companies through asset growth. The population of this study were LPDs recorded in the LPLPD of the Tabanan Regency for the period 2013 - 2014 totaling 307 LPDs. In the selection of samples carried out by purposive sampling method with the criteria of healthy LPD recorded in the LPLPD of Tabanan Regency for the period 2013-2014 and compiling annual financial reports in a row in 2013 - 2014 to obtain as many as 40 healthy LPDs. The results of the analysis show that the capital structure and Non Performing Loans can have a direct effect on asset growth and Return On Assets (ROA), as well as the capital structure and Non Performing Loans can have an indirect effect on Return On Assets (ROA) through asset growth.
\end{abstract}

Keywords: capital structure; non-performing loan; asset growth; return on assets.

\begin{abstract}
ABSTRAK
Return On Assets adalah sebuah rasio vital yang bisa digunakan dalam pengukuran kemampuan organisasi untuk investasi yang sudah tertanam dalam upaya memperoleh keuntungan. Penelitian berikut mempunyai tujuan untuk mengetahui pengaruh struktur modal dan Non Performing Loan terhadap Return On Asset (ROA) perusahaan melalui pertumbuhan aset. Populasi penelitian ini yaitu LPD yang tercatat pada LPLPD Kabupaten Tabanan periode 2013 - 2014 berjumlah 307 LPD. Didalam pemilihan sampel dilaksanakan dengan metode purposive sampling dengan kriteria LPD sehat yang dicatat di LPLPD Kabupaten Tabanan periode 2013 - 2014 serta menyusun laporan keuangan tahunan dengan berturut-turut tahun 2013 - 2014 hingga didapatkan sejumlah 40 LPD sehat. Hasil analisis menunjukkan bahwa struktur modal dan Non Performing Loan dapat berpengaruh langsung pada pertumbuhan aset dan Return On Asset (ROA), maupun struktur modal dan Non Performing Loan dapat berpengaruh tidak langsung pada Return On Asset (ROA) melalui pertumbuhan aset.
\end{abstract}

Kata kunci: struktur modal; non performing loan; pertumbuhan aset; return on asset. 


\section{PENDAHULUAN}

Bali merupakan satu diantara sekian wilayah di Indonesia yang dikenal dengan kebudayaannya, satu dari sekian keunikan di Bali yaitu eksistensi daripada desa pakraman juga desa. Lingkup desa pakraman tidaklah terbatas di peran sosial budaya juga agama, selain itu pula ekonomi juga pelayanan umum yang sumbernya dari pemerintah. Apabila dilihat beban berat yang terpikul oleh desa pakraman, tentu terpikir berapa besarnya dana yang haruslah dihabiskan oleh desa pakraman, tapi ironisnya pengeluaran desa pakraman tidak termasuk didalam kebijakan pembiayaan pemerintah.

Kebijakan pembiayaan pemerintah hanyalah sebatas sampai desa saja, namun desa pakraman pun perlu biaya yang tidaklah sedikit. Dikarenakan hal tersebut desa pakraman mempunyai tuntutan agar melakukan tata kelola perekonomian mandiri, jadi di tahun 1984 pemerintah Bali mempunyai ide mendirikan Lembaga Perkreditan Desa pada semua desa pakraman di Bali. Tahun 1984 dengan Surat Keputusan (SK) Gubernur No. 972 Tahun 1984 mengenai Pendirian Lembaga Perkreditan Desa di Provinsi Daerah Tingkat I Bali, proyek pendirian LPD mulai dilaksanakan serta adanya LPD diatur dibawah Peraturan Daerah (PERDA) yaitu Peraturan Daerah Provinsi Bali Nomor 8 Tahun 2002 Tentang Lembaga Perkreditan Desa (LPD), yang saat ini sudah berganti jadi Peraturan Daerah Provinsi Bali Nomor 3 Tahun 2007.

Didalam pengupayaan tercapainya berhasil atau tidaknya LPD agar terwujudnya tujuan, LPD haruslah dikelola dengan profesional memakai strategi 
yang cocok dan perhatian lingkungan yang penuh dengan persaingan, baik lingkungan internal ataupun lingkungan eksternal organisasi. Lingkungan internal LPD menunjukkan ada tidaknya kekuatan serta kelemahan terhadap terlibatnya aspek ataupun fungsi bisnis didalam mengelola LPD, seperti aspek manajemen ataupun perusahaan, kepengurusan LPD, keuangan, juga permodalan. Lingkungan eksternal dimana haruslah disadarkan bahwasannya didalam pengelolaan LPD secara operasional melawan persaingan daripada organisasi yang jenisnya sama masuk dalam wilayah desa, misalnya lembaga keuangan Bank ataupun lembaga keuangan bukan Bank, selain itu setiap peraturan pemerintah yang memuat aturan mengenai kelembagaan keuangan, keaadan itu memberi peluang juga tantangan dalam mengelola LPD, serta sedalam apa pemahaman pada lingkungan itu bisa menjadi masukan didalam melakukan perumusan strategi yang cocok.

Selain itu, tantangan yang dihadapi LPD adalah kredit bermasalah. Menurut Rosmilia (2009), Non Performing Loan (NPL) merupakan kredit yang kolektabilitasnya didalam perhatian khusus, kurang lancar (sub standard), diragukan (doubtfull) serta kredit macet. Menurut Bank Indonesia didalam paket kebijakan deregulasi bulan Mei tahun 1993 (PAKMEI 1993), NPL merupakan kredit yang tergolong kedalam kolektabilitas kurang lancar, diragukan serta macet. Makin tingginya rasio NPL maka tingkat likuiditas LPD pada dana pihak ketiga (DPK) jadi makin rendah. Hal tersebut terjadi karena sejumlah besar dana yang tersalur pada LPD didalam bentuk kredit yaitu simpanan dana pihak ketiga (DPK). Banyak faktor-faktor yang menjadi sebab timbulnya NPL yang bisa terklasifikasi 
jadi beberapa kelompok adalah, faktor intern bank, faktor debitur serta faktor ekstern bank.

Terdapat empat faktor yang memiliki keterkaitan yang bisa dilakukan penjelasan tumbuhnya sebuah LPD dengan cepat sebagai lembaga perantara keuangan pada provinsi Bali. Satu, tumbuhnya LPD dengan cepat itu dengan tak langsung memberikan petunjuk bahwasannya pemerintah provinsi Bali mempunyai rasa ingin politis yang kuat agar melakukan penyediaan akses kredit bagi masyarakat lewat mendirikan LPD. Dua, pertumbuhan yang sangatlah cepat di portfolio nasabah serta pinjaman LPD memberikan indikasi bahwasannya LPD baik sebagai lembaga keuangan ataupun mekanisme tata kelola cocok dengan serta bisa melakukan pemenuhan butuh atau tidaknya masyarakat Bali, khususnya pada desa. Tiga, dikarenakan masing-masing LPD melakukan operasi hanyalah pada sebuah desa adat yang wilayah cakupannya relatif kecil, anggota komunitas mempunyai informasi yang mencukupi tentang LPD serta bisa dengan mudahnya mengakses. Empat, besarnya tabungan menampilkan bahwasannya LPD tidak cuma lembaga pemberi pinjaman ( lending institution) tapi juga sebagai lembaga tabungan ( saving institution), yang mempunyai arti LPD sudah bisa melakukan peran sebagai lembaga perantara keuangan sama dengan Bank umum.

Return On Asset adalah satu diatara sekian rasio profitabilitas yang bisa digunakan untuk melakukan pengukuran mampu atau tidaknya LPD didalam memperoleh keuntungan daripada aset yang dipakai. Return On Asset yang positif memberikan petunjuk bahwasannya daripada jumlah aktiva yang digunakan dalam operasional, LPD bisa memberi keuntungan. Namun bila ROA yang negatif 
memberikan petunjuk bahwasannya dari jumlah aset yang digunakan, LPD memperoleh kerugian. Kesimpulannya apabila sebuah LPD memiliki ROA yang besar jadi memiliki peluang tinggi didalam proses peningkatan pertumbuhannya. Tapi apabila total aset yang dipergunakan tak memberi keuntungan maka LPD dapat mengalami kerugian serta bisa melakukan penghambatan pertumbuhan. ROA dipilih karena lebih memfokuskan pada kemampuan untuk memperoleh earning dalam operasi secara keseluruhan. Selain itu juga, dalam penentuan tingkat kesehatan suatu bank, penilaian ROA dianggap lebih penting daripada ROE karena pada umumnya nilai profitabilitas sebuah bank lebih diutamakan dan terukur dengan aktiva yang dananya sejumlah besar memiliki sumber dari dana masyarakat hingga ROA terasa akan mewakili didalam melakukan pengukuran tingkat profitabilitas perbankan (Dendawijaya, 2009:119).

LPD Kabupaten Tabanan dipilih sebagai obyek penelitian karena masih ditemukannya masalah mengenai kredit macet dan ketidakmampuan LPD dalam pengelolaan SDM. LPD kolaps mulai marak di Tabanan sejak tahun 2009 dengan total mencapai 49 LPD. Hingga tahun 2014, baru ada 14 LPD yang bisa dibangkitkan. Berdasarkan uraian latar belakang diatas, maka rumusan masalah dalam penelitian ini adalah : 1) Apakah struktur modal berpengaruh terhadap pertumbuhan aset ? 2) Apakah non performing loan berpengaruh terhadap pertumbuhan aset? 3) Apakah pertumbuhan aset berpengaruh terhadap return on asset ? 4) Apakah struktur modal berpengaruh terhadap return on asset ? 5) Apakah non performing loan berpengaruh terhadap return on asset? 
Menurut Husnan (2000), struktur modal merupakan pertimbangan ataupun perbandingan diantara modal asing pada modal sendiri. Struktur modal didalam organisasi mempunyai kaitan erat dengan investasi hingga didalam hal berikut dapat menyangkut asal dana yang mampu dipakai dalam proses pembiayaan proyek investasi itu. Penelitian berikut diharap mampu menjadi dukungan hasil penelitian Joni dan Lina (2010) serta Margaretha dan Ramadhan (2010) yang menyatakan bahwasannya pertumbuhan asset mempunyai pengaruh signifikan pada struktur modal. Berbeda dengan penelitian Sari (2013) menyatakan Struktur Modal tidak berpengaruh terhadap Pertumbuhan Aset. Dari uraian tersebut, maka hipotesis yang dapat dirumuskan adalah:

$\mathrm{H}_{1}$ : Struktur Modal berpengaruh positif terhadap Pertumbuhan Aset

Non Performing Loan ataupun disebut juga dengan kredit bermasalah bisa diberi arti sebagai pinjaman yang dalam kesulitan melunasi diakibatkan ada faktor kesengajaan ataupun dikarenakan faktor eksternal diluar pengendalian debitur (Setyorini, 2012:181). Dari penelitian sebelumnya Aditya Pramudita (2014) menyatakan Non Performing Loan tidak berpengaruh terhadap Pertumbuhan Aset. Sedangkan penelitian dari Latti Indirani (2006) menyatakan Non Performing Loan berpengaruh terhadap Pertumbuhan Aset. Dari uraian tersebut, maka hipotesis yang dapat dirumuskan adalah:

$\mathrm{H}_{2}$ : Non Performing Loan berpengaruh negatif terhadap Pertumbuhan Aset

Meningkatnya aktiva yang ikut dalam meningkatnya hasil operasi dapat makin melakukan penambahan percaya tidaknya pihak luar pada organisasi. 
Dengan peningkatan kepercayaan pihak eksternal pada organisasi, jadi jumlah hutang makin tinggi dibandingkan modal sendiri. Dari penelitian sebelumnya Dewi Sartika (2012) menyatakan Pertumbuhan Aset berpengaruh positif terhadap Return On Asset. Penelitian Rianto Adiputra (2013) menyatakan bahwa Pertumbuhan Aset tidak berpengaruh terhadap Return On Asset. Dari uraian tersebut, maka rumusan hipotesis yang dapat disimpulkan adalah:

$\mathrm{H}_{3}$ : Pertumbuhan Aset berpengaruh positif terhadap Return On Asset

Struktur modal memberikan petunjuk berapa besarnya sebuah organisasi dilakukan pembiayaan oleh hutang serta modal sendiri, namun profitabilitas memberikan petunjuk berapa besarnya mampu atau tidaknya organisasi didalam mendapatkan laba. Penelitian sebelumnya oleh Hari Permadi (2013) menyatakan Struktur Modal berpengaruh negatif terhadap Return On Asset, sedangkan menurut Meidera Elsa Dwi Putri (2012) menyatakan bahwa Struktur Modal berpengaruh positif tidak signifikan terhadap Return On Asset. Dari uraian tersebut, maka rumusan hipotesis yang dapat disimpulkan adalah:

$\mathrm{H}_{4}$ : Struktur Modal berpengaruh positif terhadap Return On Asset

Non Performing Loan adalah satu dari sekian dari rasio untuk mengukur risiko usaha perbankan yang memberi petunjuk besar atau tidaknya risiko kredit bermasalah yang terdapat di sebuah bank. Gelos (2006) didalam risetnya melakukan pengujian pengaruh NPL pada ROA perbankan yang mana hasil risetnya memberikan petunjuk hasil yang signifikan negatif memiliki pengaruh pada kinerja bank. Penelitian Alda Layala Diva (2013) menyatakan Non 
Performing Loan berpengaruh signifikan terhadap Return On Asset, yang berarti tingginya risiko kredit perbankan memiliki pengaruh kinerja bank hingga dibutuhkan dilaksanakannya riset lanjutan yang melakukan pengujian pengaruh non performing loan pada return on asset. Berdasar kepada uraian itu bisa terumus hipotesa sebagai berikut:

$\mathrm{H}_{5}$ : Non Performing Loan berpengaruh negatif terhadap Return On Asset

\section{METODE PENELITIAN}

Penelitian berikut memakai pendekatan kausal yang memiliki tujuan agar melihat hubungan diantara variable. Penelitian ini menggunakan sampel dari data sekunder berupa laporan keuangan yang diperoleh dari laporan tahunan LPLPD Kabupaten Tabanan tahun 2013 - 2014. Penelitian ini dilakukan untuk menguji pengaruh struktur modal dan Non Performing Loan (NPL) pada Return On Asset (ROA) menggunakan pertumbuhan aset sebagai variabel intervening.

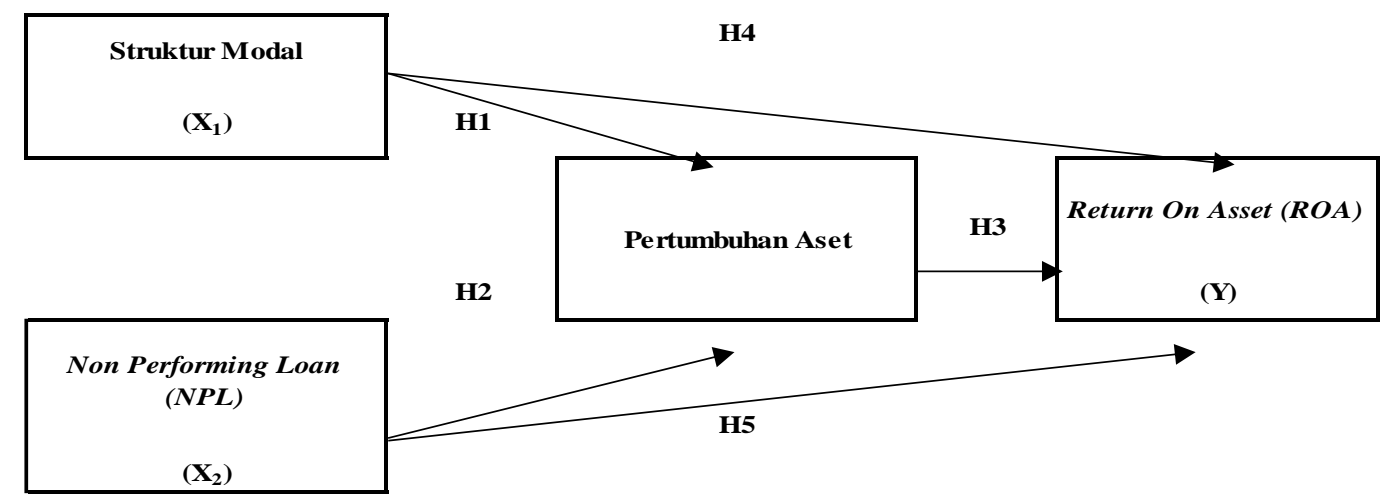

Gambar 1.

Desain Penelitian

Sumber: Data Diolah, 2018 
Penelitian ini dilakukan pada Lembaga Perkreditan Desa yang terdapat di Kabupaten Tabanan melalui Lembaga Pemberdayaan Lembaga Perkreditan Desa untuk mendapatkan informasi yang diperlukan serta memperoleh laporan keuangan tahunan Lembaga Perkreditan Desa pada tahun 2013 - 2014. Objek penelitian adalah suatu sifat dari objek yang diterapkan oleh peneliti untuk dipelajari dan kemudian memperoleh kesimpulan (Sugiyono, 2012:38). Objek penelitian ini adalah Return On Asset LPD di Kabupaten Tabanan Tahun 2014, mengenai Struktur Modal, Non Performing Loan serta Pertumbuhan Aset. Variabel terikat dalam penelitian ini adalah Return On Asset (Y). Variabel bebas dalam penelitian ini adalah struktur modal (X1) dan Non Performing Loan (X2). Variabel intervening dalam penelitian ini adalah pertumbuhan aset.

Menurut Riyanto (2001) didalam Kartika (2009), struktur modal merupakan pertimbangan diantara besarnya utang jangka panjang dengan ekuitas ataupun modal sendiri yang dipunyai organisasi. Jadi struktur modal adalah bauran diantara utang jangka panjang serta ekuitas yang bisa meningkatkan harga saham organisasi. Utang jangka pendek tak masuk kedalam struktur modal sebabnya adalah selalu mendapatkan berubahnya nominal. Riyanto (2001) memberikan pernyataan dasarnya struktur modal sebuah organisasi terdiri daripada dua komponen adalah utang jangka panjang serta modal sendiri.

Non Performing Loan adalah sebuah kategori hutang yang terklasifikasi didalam kredit bermasalah. NPL bisa disamakan dengan istilah default, yang didalam hal berikut menurut Servigny serta Renault (2004) tergambar sebagai organisasi yang mendapatkan kesulitan dengan hutang hingga mendapatkan 
kesulitan. PBI No 7/3/DPNP - 2005 Tentang Klasifikasi Kualitas Aktifa Produktif, memberi pernyataan bahwasannya hutang yang digolongkan memiliki masalah yaitu yang sudah lewat 90 hari daripada jatuh tempo. Karena hal tersebut Bank Indonesia pun sudah memutuskan cadangan yang tinggi terhadap kualitas kredit yang seperti itu.

Pertumbuhan aset adalah variable yang dilakukan pertimbangan didalam keputusan kredit. Biasanya biaya emisi saham akanlah melebihi daripada biaya penerbitan surat hutang. Dengan begitu, orgaisasi yang tingkat pertumbuhannya lebih besar memiliki kecendrungan lebih besar memakai kredit, hingga adanya hubungan positif diantara growth dengan debt equity ratio. (Brigham, 2001), organisasi yang memiliki tingkat pertumbuhan besar mempunyai kecendrungan memakai sumber dana eksternal. Hal ini didasarkan pada keyakinan kreditur atas dana yang ditanamkan kedalam perusahaan dijamin oleh besarnya asset yang dimiliki perusahaan (Martono dan Harjito, 2013: 133), maka untuk mengukur tingkat pertumbuhan aset adalah dengan menggunakan rumus sebagai berikut:

Pertumbuhan Aset $=\frac{\text { asset } t-\text { asset } t-1}{\text { asset } t-1} \times 100 \%$

Pengertian return on asset menurut para ahli yang terakhir yaitu menurut Sawir (2005:18), Return On Asset merupakan rasio yang dipakai dalam proses pengukuran mampu atau tidaknya manajemen sebuah organisasi didalam mendapatkan keuntungan dengan seluruhnya. Makin besarnya return on asset sebuah organisasi, makin besar juga tingkat laba yang diperoleh organisasi serta makin baik juga posisi organisasi itu dalam segi menggunakan aktiva. Berdasar 
kepada pengertian return on asset menurut para ahli tersebut, jadi bisa dibentuk kesimpulan bahwasannya apabila makin besarnya laba bersih yang didapatkan suatu organisasi, jadi makin baik juga kinerja organisasi tersebut. Adapun rumus perhitungan Return On Asset adalah sebagai berikut:

ROA $=$ Laba Bersih $/$ Total Aset

Data kuantitatif dalam penelitian ini adalah angka-angka yang terdapat pada laporan keuangan diperoleh dari jumlah LPD serta data mengenai struktur modal pada LPD Kabupaten Tabanan. Dalam penelitian ini data kualitatif yang digunakan adalah nama-nama LPD yang tercantum di LPLPD Kabupaten Tabanan. Sumber data didalam riset berikut yaitu data sekunder. Data sekunder merupakan data yang didapatkan dengan tidak langsung, seperti lewat media perantara contohnya orang lain ataupun dokumen (Sugiyono, 2012). Data sekunder didalam riset berikut didapatkan daripada laporan tahunan yang didapat dari LPLPD Kabupaten Tabanan.

Populasi merupakan wilayah general yang terdiri dari obyek ataupun subyek yang memiliki kualitas serta karakter tertentu serta ditetapkan oleh peneliti agar dipelajari lalu ditarik sebuah kesimpulan (Sugiyono, 2012). Populasi didalam riset berikut yaitu semua LPD sejumlah 307 LPD. Dari jumlah tersebut diklasifikasikan ke dalam kategori sebagai berikut: 207 LPD sehat, 22 LPD cukup sehat, 14 LPD kurang sehat, dan 64 LPD tidak sehat/macet. Dalam penelitian ini sampel diambil menggunakan metode Non Probability Sampling dimana teknik penentuan sampel yang tak memberi peluang ataupun kesempatan 
yang sama bagi tiap anggota populasi agar terpilih sebagai sampel. Teknik pengambilan sampel yang dipakai adalah purposive sampling. Purposive sampling merupakan penyampelan dengan kriteria berupa suatu pertimbangan tertentu (Sugiyono, 2012:122). Teknik pengambilan sampel yang dipakai adalah purposive sampling dengan syarat seperti berikut: 1) Menerbitkan laporan keuangan tahunan (annual report) pada periode 2013-2014. 2) Data mengenai variabel tersedia lengkap pada laporan keuangan dan tahunan periode 20132014. Dengan demikian, dalam penelitian ini menggunakan 40 sampel LPD dari rincian 10 kecamatan di Kabupaten Tabanan diambil masing-masing 4 LPD yang memenuhi kriteria di atas dan tergolong LPD sehat. Pemilihan sampel menggunakan kategori yang sehat karena sampel tersebut diasumsikan mewakili kebutuhan analisis.

Teknik analisis data didalam riset berikut memakai teknik analisis path (path analysis). Analisis jalur merupakan sebuah teknik yang berkembang daripada regresi linier ganda. Teknik berikut dipakai dalam melakukan pengujian besar tidaknya kontribusi yang ditampilkan oleh koefisien jalur di tiap-tiap diagram jalur daripada hubungan kausal antara variable $\mathrm{X}_{1} \mathrm{X}_{2}$ serta $\mathrm{X}_{3}$ pada $\mathrm{Y}$ juga dampak variabel itu pada $\mathrm{Z}$. "Analisis jalur ialah suatu teknik untuk menganalisis hubungan sebab akibat yang tejadi pada regresi berganda jika variabel bebasnya mempengaruhi variabel tergantung tidak hanya secara langsung tetapi juga secara tidak langsung". (Robert D. Retherford, 1993). Tahapan analisis yang harus dilakukan adalah statistik deskriptif, uji asumsi klasik, koefisien determinasi, uji kelayakan model (uji F) dan uji statistik (uji T). 


\section{HASIL DAN PEMBAHASAN}

LPD yang dijadikan objek dan sampel dalam penelitian ini adalah LPD yang terdaftar di LPLPD Kabupaten Tabanan. Dari data yang diperoleh sepanjang tahun 2013-2014 terdapat 307 LPD, dimana dari 307 LPD tersebut diambil sebanyak 40 sampel yang memenuhi persyaratan purposive sampling dan dinyatakan sehat/tidak pailit. Statistik deskriptif didalam riset berikut tersaji agar memberi informasi tentang karakter variable-variable riset. Uji statistik deskriptif memiliki cakupan nilai minimum, nilai maksimum, serta standar deviasi daripada data riset. Hasil uji statistik deskriptif serta tiap-tiap variable tersaji didalam Tabel 1.

Tabel 1.

Tabel Statistik Deskriptif

\begin{tabular}{lrrrrr}
\hline & N & Mean & Std. Deviation & Minimum & Maximum \\
\hline ROA & 40 & 3.191 .551 & 14.568 .611 & .8922 & 75.132 \\
Pertumbuhan Aset & 40 & 31.074 .454 & 784.461 .403 & -633.105 & 2.698 .528 \\
Struktur Modal & 40 & 36.289 .250 & 154.376 .459 & 56.200 & 641.500 \\
NPL & 40 & .137035 & .1089762 & .0122 & .4767 \\
\hline Sumber: Data Diolah, 2018 & & & &
\end{tabular}

Berdasar kepada hasil uji statistic deskriptif di Tabel 1 bisa dijelaskan bahwasannya variable struktur modal (X1) rata-ratanya (mean) sejumlah 36,289250 dengan standar deviasi sejumlah 15,4376459 yang memberikan petunjuk variasi yang ada pada struktur modal. Struktur modal tertinggi yaitu 64,1500 dan yang terendah yaitu 5,6200. Variabel Non Performing Loan (X2) rataratanya (mean) sejumlah 0,137035 dengan standar deviasi sejumlah 0,1089762 yang memberikan petunjuk variasi yang ada didalam Non Performing Loan. Nilai 
Non Performing Loan paling tinggi adalah 0,4767 serta yang paling rendah adalah 0,0122. Variabel Pertumbuhan Aset (Z) rata-ratanya (mean) sejumlah 31,074454 dengan standar deviasi sejumlah 78, yang memberikan petunjuk variasi yang ada didalam Pertumbuhan Aset. Pertumbuhan Aset tertinggi yaitu 269,8528 dan yang terendah yaitu -63,3105. Variabel ROA (Y) rata-ratanya (mean) sebesar 3,191551 dengan standar deviasi sebesar 1,4568611 yang memberikan petunjuk variasi yang ada didalam ROA. ROA tertinggi yaitu 7,5132 dan yang terendah yaitu 0,8922. Uji normalitas ini memiliki tujuan melakukan pengujian apa didalam model regresi variabel pengganggu (residual) mempunyai distribusi normal.

Tabel 2.

Hasil Uji Normalitas

\begin{tabular}{llll}
\hline No & Persamaan & Kolmogorov-Smirnov Z & Asym. Sig. (2-tailed) \\
\hline 1 & $\mathrm{Z}=\alpha+\beta_{1} \mathrm{X}_{1}+\beta_{2} \mathrm{X}_{2}+\mathrm{e}$ & 1,159 & 0,136 \\
\hline $2 \quad \mathrm{Y}=\alpha+\beta_{1} \mathrm{X}_{1}+\beta_{1} \mathrm{X}_{2}+\beta_{3} \mathrm{Z}+\mathrm{e}$ & 0,592 & 0,874 \\
\hline Sumber: Data Diolah, 2018 & &
\end{tabular}

Uji normalitas dilakuka pengujian dengan uji Kolmogorov-smirnov, dimana apabila koefisien Asym. Sig. (2-tailed) melebihi dari $\alpha=0,05$ memiliki arti data mempunyai distribusi normal. Nilai Kolmogorov-smirnov serta asym. Sig. (2tailed) persamaan 1 juga persamaan 2 melebihi daripada 0,05. Hasil tersebut memberikan petunjuk bahwasannya data sudah memiliki distribusi secara normal. Uji multikolinearitas agar tahu hubungan yang memiliki makna (korelasi) diantara tiap-tiap variable independen dengan sebuah model regresi. 
Tabel 3.

Hasil Uji Multikolinearitas

\begin{tabular}{lllll}
\hline No & Persamaan & Variabel & Tolerance & VIF \\
\hline \multirow{2}{*}{1} & \multirow{2}{*}{$\mathrm{Z}=\alpha+\beta_{1} \mathrm{X}_{1}+\beta_{2} \mathrm{X}_{2}+\mathrm{e}$} & $\mathrm{X} 1$ & 0,97 & 1,031 \\
& & $\mathrm{X} 2$ & 0,97 & 1,031 \\
\hline \multirow{2}{*}{2} & $\mathrm{Y}=\alpha+\beta_{1} \mathrm{X}_{1}+\beta_{1} \mathrm{X}_{2}+\beta_{3} \mathrm{Z}+\mathrm{e}$ & $\mathrm{X} 1$ & 0,957 & 1,045 \\
& & $\mathrm{X} 2$ & 0,968 & 1,033 \\
& & $\mathrm{Y}$ & 0,987 & 1,013 \\
\hline
\end{tabular}

Sumber: Data Diolah, 2018

Hasil uji multikolinearitas pada Tabel 3 menunjukkan nilai tolerance untuk setiap variabel independen pada persamaan 1 dan persamaan 2 lebih besar dari 0,10 dan nilai VIF-nya lebih kecil dari 10, sehingga model ini dapat dikatakan bebas dari multikolinaeritas. Uji heteroskedastisitas bertujuan untuk menguji apakah dalam model regresi terjadi ketidaksamaan variance dari residual satu pengamatan ke pengamatan lainnya.

Tabel 4.

Hasil Uji Heteroskedastisitas

\begin{tabular}{lllll}
\hline No & Persamaan & Variabel & $\mathrm{T}$ & Sig. \\
\hline \multirow{2}{*}{01.00} & \multirow{2}{*}{$\mathrm{Z}=\alpha+\beta_{1} \mathrm{X}_{1}+\beta_{2} \mathrm{X}_{2}+\mathrm{e}$} & $\mathrm{X} 1$ & 0,688 & 0,496 \\
& & $\mathrm{X} 2$ & 0,211 & 0,834 \\
\hline \multirow{2}{*}{02.00} & $\mathrm{Y}=\alpha+\beta_{1} \mathrm{X}_{1}+\beta_{1} \mathrm{X}_{2}+\beta_{3} \mathrm{Z}+\mathrm{e}$ & $\mathrm{X} 2$ & $-1,578$ & 0,123 \\
& & $\mathrm{Y}$ & 0,19 & 0,85 \\
& & & & \\
\hline
\end{tabular}

Sumber: Data Diolah, 2018

Hasil uji heterokedasitas pada Tabel 4 memberi petunjuk bahwasannya seluruh variable persamaan 1 serta persamaan 2 mempunyai nilai signifikansi lebih dari 0,05 hingga data dari penelitian ini bisa dibentuk kesimpulan bebas daripada heterokedasitas. 
Proses menguji data di riset berikut memakai analisis jalur (path analysis) guna melakukan pengujian pola hubungan yang memberi ungkapan pengaruh variable ataupun sejumlah variabel pada variable lain, baik pengaruh langsung ataupun pengaruh tak langsung. Secara teoritis, hubungan diantara variable bisa dibentuk model kedalam bentuk diagram path. sehingga membentuk sistem persamaan berikut.

$\mathrm{Z}=\alpha_{1} \mathrm{X}_{1}+\alpha_{2} \mathrm{X}_{2}+\mathrm{e}_{1}$

$\mathrm{Y}=\beta \mathrm{Z}+\mathrm{e}_{2}$

Untuk pemeriksaan terhadap asumsi, dapat dilakukan dengan melihat susunan model teoritis yang telah dibangun dengan memperlihatkan bentuk hubungan antar variabel adalah linier, yaitu system aliran ke satu arah, dimana hubungan antara ei dengan variabel $\mathrm{X}$ saling balas, serta tak adanya variabel endogen yang memiliki pengaruh bolak-balik, seperti dapat dilihat di gambar diagram path seperti.



Gambar 2.

Diagram Jalur

Sumber: Data Diolah, 2018 
Berdasar kepada Gambar 2 jadi hubungan diantara variable yaitu linier, atau sistem aliran ke satu arah, dimana hubungan diantara ei saling bebas, serta tak ada variabel endogen yang memiliki pengaruh bolak-balik. Di dalam analisis jalur, pengaruh langsung disebut dengan koefisien pi namun pengaruh tidak langsung serta pengaruh total bisa dihitung dengan proses menghitung terpisah. Untuk menetapkan dugaan parameter dilaksanakan dengan analisis linier regresi lewat (SPSS) Statistical Product and Service Solution.

Dari pengujian data yang telah dilakukan maka diperoleh hasil pada Tabel 5.

Tabel 5.

Hasil Analisis Jalur Persamaan Regresi I

\begin{tabular}{lrrr}
\hline \multicolumn{1}{c}{ Variabel } & Koefisien Regresi & \multicolumn{1}{c}{ T } & \multicolumn{1}{c}{ Signifikansi } \\
\hline \multicolumn{1}{c}{ Struktur Modal } & 0.309 & 2.016 & 0.035 \\
$\quad N P L$ & -0.178 & -1.162 & 0.025 \\
F Hitung & & & $\mathbf{1 0 . 7 5 9}$ \\
Signifikansi & & $\mathbf{0}$ \\
R $_{1}$ & & $\mathbf{0 , 6 2 5}$ \\
Adjusted R1 Square & & & $\mathbf{0 , 3 5 5}$
\end{tabular}

Sumber: Data Diolah, 2018

Tabel 5 menjelaskan hasil pengolahan data pada jalur persamaan regresi I, berikut dilanjutkan dengan hasil pengolahan data jalur persamaan regresi II. Berdasar kepada proses menghitung terhadap substruktur 1 serta 2, jadi bisa didapatkan besarnya pengaruh langsung, pengaruh tidak langsung juga pengaruh total diantara variabel. 
Tabel 6

Hasil Analisis Jalur Persamaan Regresi II

\begin{tabular}{lrrr}
\hline \multicolumn{1}{c}{ Variabel } & Koefisien Regresi & \multicolumn{1}{c}{ T } & \multicolumn{1}{c}{ Signifikansi } \\
\hline Pertumbuhan Aset & 0.062 & 0.334 & 0.039 \\
$\quad$ Struktur Modal & -0.372 & -2.307 & 0.027 \\
$\quad$ F Hitung & -0.020 & -0.129 & 0.034 \\
Signifikansi & & & $\mathbf{1 1 , 8 0 8}$ \\
R1 & & & $\mathbf{0}$ \\
Adjusted R1 Square & & & $\mathbf{0 , 6 6 4}$ \\
Sumber: Data Diolah, 2018 & & & $\mathbf{0 , 4 0 3}$ \\
$\quad$ & & \\
\hline
\end{tabular}

Besarnya pengaruh struktur modal dan non performing loan pada pertumbuhan aset secara parsial, serta pengaruh struktur modal dan no performing loan pada ROA secara parsial dilihat dari nilai beta atau Standardized Coefficient adalah sebagai berikut: a) Pengaruh struktur modal pada pertumbuhan aset $=2,016$, b) Pengaruh non performing loan pada pertumbuhan $=-1,162$, c) Pengaruh pertumbuhan aset pada $\mathrm{ROA}=0,334$, d) Pengaruh struktur modal pada ROA = 2,307, e) Pengaruh non performing loan pada ROA = -0,129.

Pengaruh tidak langsung yang terjadi antar variabel dapat diketahui sebagai berikut. a) Pengaruh struktur modal pada ROA melalui pertumbuhan aset $=(2,016$ $\mathrm{x} 0,334)=0,673344$, b) Pengaruh non performing loan pada ROA melalui pertumbuhan aset $=(-1,162 \times 0,334)=-0,388108$. Pengaruh langsung serta pengaruh tidak langsung masing-masing variabel dapat digunakan untuk mencari pengaruh total dari variabel tersebut yaitu sebesar $-0,962764$. Persamaan structural untuk model penelitian ini adalah: 
Struktur 1:

$Z=\alpha_{1} X_{1}+\alpha_{2} X_{2}+e_{1}$

$Z=2,016 X_{1}+(-1,162) X_{2}$

Pengaruh error $(\mathrm{Pei})=\sqrt{ } 1-\mathrm{R}^{2}$

Pei $=\sqrt{ } 1-0,391=\sqrt{ } 0,609=0,780$

Struktur 2:

$\mathrm{Y}=\beta \mathrm{Z}_{1}+\mathrm{e}_{2}$

$\mathrm{Y}=0,334 \mathrm{Z}$

Pengaruh error $\left(\right.$ Pei) $=\sqrt{ } 1-\mathrm{R}^{2}$

Pei $=\sqrt{ } 1-0,440=\sqrt{ } 0,56=0,7481$

Ada dua indicator untuk melakukan pemeriksaan validitas model, yaitu koefisien determinasi total dan theory trimming dimana hasilnya dapat disajikan sebagai berikut. Hasil perhitungan koefisien determinasi total didapatkan hasil sebesar 0,66 Artinya, keberagaman data yang bisa dijelaskan oleh model yaitu sejumlah 66 persen ataupun dengan kata lain informasi yang terdapat didalam data sejumlah 66 persen bisa dipaparkan oleh model, lalu sisanya sebesar 34 persen dipaparkan oleh variable lainnya serta error.

Theory Trimming dilaksanakan dengan membuang jalur-jalur yang nonsignifikan supaya diperoleh model yang bisa mendapat dukungan dari data empiric. Uji validasi di tiap-tia jalur dalam pengaruh langsung merupakan disamakan regresi, memakai nilai $\mathrm{p}$ daripada uji t dimana prose uji koefisien regresi variable diakukan dengan cara parsial yang nilai tiap-tiap $\mathrm{X}_{1}$ yaitu 2,016 serta $-2,307$ juga 
$\mathrm{X}_{2}$ yaitu $-1,162$ serta $-0,129$ dan $\mathrm{Z}$ yaitu 0,334 . Disamping hal tersebut yang terlihat daripada nilai p_value, suatu model memberikan hasil bentuk hubungan yang valid,

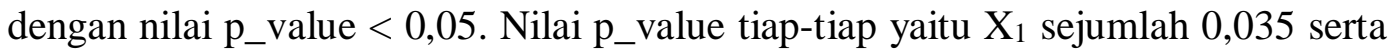
0,027, dan $\mathrm{X}_{2}$ sejumlah 0,025 serta 0,034, lalu Z sejumlah 0,039. Berdasar kepada hasil itu bisa dibentuk pernyataan bahwasannya seluruh jalur yang dipakai didalam model riset berikut valid juga sahih.

Berdasar kepada hasil proses menghitung didapatkan taraf signifikansi penelitian untuk variable jumlah pilihan saham sejumlah $0,035<0,05$, hingga struktur modal mempunyai pengaruh terhadap pertumbuhan aset. Berdasar kepada hasil proses menghitung didapatkan taraf signifikansi penelitian untuk variable harga eksekusi sebesar $0,025<0,05$, sehingga Non Performing Loan memiliki pengaruh pada pertumbuhan aset. Berdasarkan hasil perhitungan diperoleh taraf signifikansi penelitian untuk variabel manajemen laba sebesar 0,039<0,05, sehingga pertumbuhan aset berpengaruh pada Return On Asset. Berdasar kepada hasil proses menghitung didapatkan taraf signifikansi penelitian untuk variabel jumlah opsi saham sebesar $0,027<0,05$, sehingga struktur modal memiliki pengaruh pada nilai perusahaan. Berdasarkan hasil proses menghitung didapatkan taraf signifikansi penelitian untuk variabel harga eksekusi sebesar $0,034<0,05$, sehingga Non Performing Loan mempunyai pengaruh pada Return On Asset.

Berdasarkan hasil penelitian terhadap pengujian hipotesis, ditemukan bahwa struktur modal berpengaruh positif pada pertumbuhan aset. Bukti empiris menunjukkan bahwa struktur modal berpengaruh signifikan pada pertumbuhan aset. Menurut Husnan (2000), struktur modal merupakan pertimbangan ataupun 
perbandingan diantara modal asing dengan modal sendiri. Struktur modal didalam organisasi memiliki keterkaitan erat dengan investasi hingga didalam hal akan bersangkut paut dengan asal dana yang dapat dipakai dalam pembiayaan projek investasi itu. Meningkatnya asset yang dibarengi dengan meningkatnya hasil operasi akanlah makin menambahkan kepercayaan pihak eksternal pada organisasi. Dengan peningkatan kepercayaan pihak eksternal pada organisasi, jadi jumlah hutang makin besar dari modal sendiri. Hal tersebut didasarkan pada keyakinan kreditor atas dana yang tertanam pada organisasi terjamin oleh tingginya aktiva yang dipunya organisasi (Ang, 1997). Namun meningkatnya jumlah hutang yang melebihi modal sendiri memberikan petunjuk debt to total assets ratio makin tinggi juga. Dengan demikian tumbuhnya aktiva memberikan prediksi pengaruh positif pada struktur modal yang mempunyai arti makin besarnya tingkat pertumbuhan aset organisasi, jadi makin tinggi juga tingkat hutang per nilai assetnya. Riset berikut pula diperkuat hasil riset Joni dan Lina (2010) serta Margaretha dan Ramadhan (2010) yang menyatakan bahwasannya pertumbuhan aktiva memiliki pengaruh signifikan terhadap struktur modal.

Berdasarkan pada hasil penelitian terhadap pengujian hipotesis, ditemukan bahwa Non Performing Loan berpengaruh negatif pada pertumbuhan aset. Non Performing Loan ataupun disebut juga dengan kredit bermasalah bisa diberi arti sebagai pinjaman yang dalam kesulitan melunasi diakibatkan ada faktor kesengajaan ataupun dikarenakan faktor eksternal diluar pengendalian debitur (Setyorini, 2012:181). Sejalan dengan penelitian yang dilakukan oleh Setyaningsih (2013) menyatakan bahwa variabel NPL tidak berpengaruh signifikan terhadap 
variabel pertumbuhan aset. Sikap kehati-hatian bank dalam menjaga resiko kegagalan kredit mengakibatkan jumlah dana yang dimiliki oleh bank tidak terealisasi dengan baik. Dengan modal bank yang besar, berdampak pada besarnya kas yang menganggur karena tidak dapat tersalurkanya kredit yang memberikan pendapatan bunga, yang akan menguntungkan bank tersebut. Kredit macet memiliki akibat negatif untuk dua belah pihak, baik itu bank maupun nasabahnya. Untuk nasabah akibatnya merupakan mereka haruslah menanggung kewajiban yang sangat berat pada bank. Mengingat tiap pinjaman yang berasal dari bank mempunyai bunga, jadi besarnya kewajiban nasabah makin lama akanlah makin tambah tinggi apabila tidak lunas segera. Namun bank akibatnya jauh lebih serius dikarenakan selain dana yang tersalur dalam kredit asalnya dari masyarakat, kredit macet pula memberikan akibat perbankan mengalami kurangnya dana hingga memberikan pengaruh kegiatan usaha perbankan.

Berdasar kepada hasil riset untuk pengujiian hipotesis didapatkan bahwasannya pertumbuhan aset memiliki pengaruh positif terhadap nilai perusahaan. Hal ini berarti meningkatnya aktiva yang diikuti dengan meningkatnya hasil operasi akan makin memberi tambahan kepercayan pihak eksternal pada organisasi. Dengan peningkatan kepercayaan pihak eksternal pada organisasi, menyebabkan jumlah hutang makin tinggi dibandingkan modal sendiri. Dari penelitian sebelumnya Dewi Sartika (2012) menyatakan Pertumbuhan Aset berpengaruh positif terhadap Return On Asset.

Organisasi tak bisa berjalan tanpa adanya sistim penjualan yang bagus. Penjualan adalah ujung tombak dari suatu organisasi. Ramalan penjualan yang 
cocok sangat dibutuhkan, supaya organisasi bisa melakukan persiapan seluruh suatunya yang dibutuhkan dalam proses produksi. Dengan memakai rasio bertumbuhnya penjualan, organisasi bisa tahu tren penjualan dari barang atau jasanya dari tahun ke tahun. Brigham dan Houston (2006) menyatakan bahwasannya penjualan haruslah bisa menutupi pembiayaan hingga bisa meningkatkan laba. Maka organisasi bisa melakukan penentuan langkah-langkah yang bisa diambil dalam melakukan antisipasi mungkin atau tidaknya naik ataupun turunnya penjualan di tahun berikutnya. Apabila penjualan dilakukan peningkatan, maka asset juga haruslah dilakukan penambahan sedangkan pada sisi lainnya, bila organisasi tahu dengan pasti permintaan penjualan yang akan datang, hasil daripada tagihan piutangnya, juga jadwal produksinya, organisasi bisa mengatur jadwal jatuh tempo hutangnya supaya cocok dengan arus kas bersih yang akan datang. Hal ini akan berakibat, keuntungan mampu dimaksimalkan.(Horne dan Wachowicz, 2009).

Berdasarkan pada hasil penelitian terhadap pengujian hipotesis, ditemukan bahwa struktur modal berpengaruh signifikan pada Return On Asset. Hal ini berarti struktur modal memberikan petunjuk berapa besar sebuah organisasi dibiayai oleh utang serta modal sendiri, sedangkan profitabilitas memberikan petunjuk berapa besar mampu atau tidaknya organisasi didalam mendapatkan laba. Penelitian sebelumnya oleh Meidera Elsa Dwi Putri (2012) menyatakan bahwa Struktur Modal berpengaruh positif terhadap Return On Asset. Struktur modal menurut Gittman \& Zutter (2011) adalah sebuah area yang kompleks dalam keputusan finansial perusahaan karena saling berkaitan dengan variabel yang mempengaruhi keputusan finansial. Struktur modal yang buruk akan memberikan 
biaya modal yang tinggi. Sedangkan struktur modal yang efektif bisa menurunkan biaya modal sehingga bisa memberikan ruang yang lebih untuk proyek proyek dan memberikan nilai tambah pada perusahaan.

Berdasarkan pada hasil penelitian terhadap pengujian hipotesis, ditemukan bahwa Non Performing Loan berpengaruh negatif pada Return On Asset. Hal ini berarti bahwa Non Performing Loan (NPL) adalah pinjaman yang mengalami kesulitan proses untuk lunas karena ada faktor kesengajaan ataupun dikarenakan faktor eksternal diluar kendali debitur (Dahlan, Siamat, 2012:21). Meningkatnya Non Performing Loan (NPL) memberikan indikasi ada peningkatan kredit yang memiliki masalah terhadap total kredit yang dipunyai oleh perbankan. Apabila Non Performing Loan (NPL) mendapatkan peningkatan, dapat berakibat pendapatan yang harusnya didapatkan daripada bunga pinjaman dapat mengalami penurunan. Dengan rendahnya pendapatan bunga jadi mampu mengakibatkan peurunan profitabilitas. Akibat daripada turunnya laba maka return on asset pula makin rendah, sebab laba perusahaan merupakan salah satu komponen yang menambah Return On Asset.

\section{SIMPULAN DAN SARAN}

Berdasarkan pembahasan atas hasil pengujian hipotesis yang telah diuraikan sebelumnya, maka diperoleh kesimpulan 1) Struktur modal berpengaruh positif terhadap pertumbuhan aset. Dengan adanya pengaruh tersebut, membuktikan perubahan yang terjadi pada struktur modal akan berdampak pada pertumbuhan aset. 2) Non Performing Loan berpengaruh negatif pada Pertumbuhan Aset. Hal tersebut menandakan bahwa Non Performing Loan mengganggu pertumbuhan aset. 
Semakin besar tingkat NPL, maka semakin buruk kualitas kredit bank yang menyebabkan jumlah kredit bermasalah semakin besar. 3) Pertumbuhan Aset berpengaruh positif pada Return On Asset. Pertumbuhan aset yang positif menunjukkan bahwa pengaruh yang diberikan berdampak signifikan pada Return On Asset. 4) Struktur Modal berpengaruh positif pada Return On Asset. Pengaruh tersebut membuktikan struktur modal yang terencana dengan baik akan memberikan dampak positif pada Return On Asset. 5) Non Performing Loan berpengaruh negatif pada Return On Asset. Hal tersebut menandakan Non Performing Loan menghambat perkembangan Return On Asset.

Adapun saran yang dapat disampaikan kepada peneliti selanjutnya agar menambahkan variabel intervening selain pertumbuhan aset, seperti kualitas Sumber Daya Manusia dan likuiditas perusahaan dikarenakan keterbatasan waktu yang dimiliki penulis.

\section{REFERENSI}

Abidin, Z., Sunardi. (2009). Yogyakarta Air Borne Quality Based on the Lead Particulate Concentration. Indo J Chem: 9 (3): 425 - 431.

Cahyono, Dicky Dwi, and Sri Adji Prabawa. (2014) Pengaruh Ukuran Perusahaan, Profitabilitas, Pertumbuhan Aset, Dan Risiko Bisnis Terhadap Struktur Modal Pada Perusahaan Manufaktur Yang Terdaftar Di BEI Periode 2008-2012. The Manager Review Jurnal Ilmiah Manajemen 10(1) 75-90.

Diva, Alda Layala. (2013). Pengaruh Rasio CAR, NPL, BOPO, LDR, DAN NIM Terhadap Profitabilitas Perbankan "(Studi pada Bank Umum di Indonesia yang terdaftar di Bursa Efek Indonesia periode 2007-2012).

Ghozali, Imam. (2012). Aplikasi Analisis Multivariate Dengan Program SPSS. Badan Penerbit Universitas Diponegoro. Semarang.

Hanafi, Mamduh M. dan Abdul Halim. (2009). Analisis Laporan Keuangan. (Edisi Keempat). Yogyakarta: YKPN. 
Karim, Mohd Zaini Abd, Sok-Gee Chan, and Sallahudin Hassan. (2010). Bank efficiency and non-performing loans: Evidence from Malaysia and Singapore. Prague Economic Papers 19(2) 118-132.

Kartika, Andi. (2009). Faktor-Faktor yang Mempengaruhi Struktur Modal Pada Perusahaan Manufaktur yang Go Public di BEI. Jurnal keuangan dan Perbankan. Vol.1, No.2. Pp: 105-122.

Kusumajaya, Dewa Kadek Oka. (2011) Pengaruh struktur modal dan pertumbuhan perusahaan terhadap profitabilitas dan nilai perusahaan pada perusahaan manufaktur di bursa efek Indonesia. Unpublished Thesis, Universitas Udayana, Denpasar.

Muqorrobin, Agus, and Sri Padmantyo. (2011). Analisis Variabel yang Mempengaruhi Kredit Macet Perbankan di Indonesia.

Novera, Elza. (2013). Pengaruh Pertumbuhan Aset, Kebijakan Dividen Dan Likuiditas Terhadap Beta Saham (Studi Empiris pada Perusahaan Finance yang terdaftar di BEI). Jurnal Akuntansi (1.3).

Permadi, Hari. (2013). Pengaruh Struktur Modal Terhadap Profitabilitas PT INDOSAT, Tbk. Diss. Universitas Pendidikan Indonesia.

Pramudita, Aditya, and Imam Subekti. (2014). Pengaruh Ukuran Bank, Manajemen Aset Perusahaan, Kapitalisasi Pasar danProfitabilitas terhadap Kredit Bermasalah pada Bank yang terdaftar di BEI." Jurnal Ilmiah Mahasiswa FEB 2(1).

Putri, Meidera Elsa Dwi. (2013). Pengaruh Profitabilitas, Struktur Aktiva dan Ukuran Perusahaan terhadap Struktur Modal pada Perusahaan Manufaktur Sektor Industri Makanan dan Minuman yang Terdaftar di Bursa Efek Indonesia (BEI). Jurnal Manajemen 1.01.

Rosmilia, Rita. (2009). Pelaksanaan Penyelesaian Kredit Bermasalah (Studi Di PT. Bank Rakyat Indonesia (Persero) Tbk. Cabang Semarang Pattimura). Diss. PROGRAM PASCA SARJANA UNIVERSITAS DIPONEGORO.

Saba, Irum, Rehana Kouser, and Muhammad Azeem. (2012). Determinants of Non Performing Loans: Case of US Banking Sector." The Romanian Economic Journal, Year XV 44.

Sari, Devi Verena, and A. Mulyo Haryanto. (2013). Pengaruh Profitabilitas, Pertumbuhan Aset, Ukuran Perusahaan, Struktur Aktiva Dan Likuiditas Terhadap Struktur Modal Pada Perusahaan Manufaktur Di Bursa Efek Indonesia Tahun 2008-2010. Diss. Fakultas Ekonomika dan Bisnis.

Sartika, Dewi. (2012). Analisis Pengaruh Ukuran Perusahaan, Kecukupan Modal, Kualitas Aktiva Produktif Dan Likuiditas Terhadap Return On Assets (ROA)(Studi Kasus Pada Bank Umum Syariah di Indonesia Periode 20062010). 
Setyorini, (2012). Analisis Faktor-faktor yang Mempengaruhi Kinerja Keuangan pada Industri Perbankan di Bursa Efek Indonesia, Socientia Jurnal Ilmuilmu Sosial. Vo.4 No.1:179-185

Setyosari, Punaji, (2010). Metode Penelitian Pendidikan dan Pengembangan. Jakarta : Kencana.

Stice, James D, dkk. (2009). Akuntansi Keuangan Intermediate Accounting Buku 1.

Sudana, I Made. (2011). Manajemen keuangan perusahaan Teori \& Praktik. Jakarta: Erlangga.

Sugiyono, (2012). Metode Penelitian Bisnis. (Cetakan Ke 16). Bandung: Penerbit Alfabeta.

Wardhani, Sukma, and Maruto Umar Basuki. (2011). Analisis Pengaruh Spread Tingkat Suku Bunga Bank, CAR, DAN NPL Terhadap Penyaluran Kredit UMKM Oleh Perbankan Di Indonesia. Diss. Universitas Diponegoro.

Weston, J. Fred \& Thomas E. Copeland. (2010). Manajemen Keuangan. Jilid 2, Tangerang: Bina Rupa Aksara.

Wright, Peter, Mark Kroll, Ananda Mukhreji, Michael L. Pettus. (2009). Do the Conti-ngencies of External Monitoring, Ownership Incentives, or Free Cash Flow Explain Opposing Firm Performance Expectations?", Journal Management Governance, 13, pp: 215-243. 